\title{
Trudności w diagnostyce i leczeniu włókniakowatości śródpiersia. Opis przypadku
}

\author{
Diagnostic and therapeutic difficulties in mediastinal fibromatosis. Case report \\ Praca nie była finansowana
}

\begin{abstract}
Mediastinal fibromatosis is a very rare mesenchymal tumor originated from fibrous tissue. A case of 26-year old men with mediastinal tumor causes respiratory insufficiency and dysphagia is described. This sympthoms occured due to esophageal impression and infiltration with occlusion of main left bronchus by mediastinal tumor. Ethiology of the tumor was established based on histopathology assesment of the tissue samples taken during explorative thoracotomy after 3 years and many other diagnostic procedures undertaken. The authors describe difficulties in diagnosis of mediastinal tumors, especially those rare observed.
\end{abstract}

Key words: mediastinal tumor, mediastinal fibromatosis, explorative thoracotomy

Pneumonol. Alergol. Pol. 2015; 83: 60-65

\section{Streszczenie}

Włókniakowatość (fibromatosis) śródpiersia to bardzo rzadki mezenchymalny guz wywodzący się z tkanki włóknistej. W pracy przedstawiono przypadek 26-letniego mężczyzny z guzem śródpiersia wywołującym niewydolność oddechową oraz dysfagię. Objawy te spowodowane były uciskiem przełyku oraz naciekaniem i zamknięciem oskrzela głównego lewego przez masę guzowatą śródpiersia. Etiologia guza została ostatecznie ustalona na podstawie badania histopatologicznego wycinków pobranych podczas torakotomii próbnej dopiero po 3 latach i przeprowadzeniu wielu badań diagnostycznych. Autorzy opisują trudności w diagnostyce guzów śródpiersia, szczególnie tych rzadko występujących.

Słowa kluczowe: guz śródpiersia, włókniakowatość śródpiersia, torakotomia próbna

Pneumonol. Alergol. Pol. 2015; 83: 60-65

\section{Wstęp}

Włókniakowatość (fibromatosis) jest zaliczana do guzów desmoidalnych, a wywodzi się z fibroblastów. Jest to rzadka choroba, która stanowi około 0,03\% wszystkich nowotworów oraz około 3,5\% guzów włóknistych, zaś jej występowanie szacuje się na około 2-4 przypadki na milion osób rocznie. Fibromatoza może występować jako postać powierzchowna (np. przykurcz Dupuytrena) albo jako postać głęboka (guz o typie desmoidu). Do postaci głębokiej zalicza się postać śródbrzuszną oraz pozabrzuszną [1]. Guz ten częściej występuje u kobiet, ale według niektórych autorów proporcje płci są podobne, opisano także serię pacjentów z przewagą mężczyzn [1]. Szczyt występowania przypada na drugą i trzecią dekadę życia, lecz zdarza się także w innych grupach

Address for correspondence: Małgorzata Wojtyś, Specjalistyczny Szpital im.prof. Alfreda Sokołowskiego, Klinika Chirurgii Klatki Piersiowej i Transplantacji,

ul. Alfreda Sokołowskiego 11, 70-891 Szczecin-Zdunowo

DOI: 10.5603/PiAP.2015.0009

Received 15.06.2014

Copyright (C) 2015 PTChP

ISSN 0867-7077 
wiekowych [2]. Etiologia włókniakowatości nie jest znana. Może być związana z niektórymi zespołami genetycznymi jak rodzinna polipowatość gruczolakowata (FAP, familial adenomatous polyposis) albo zespół Gardnera [1]. Powstawaniu tego nowotworu mogą sprzyjać urazy (też operacyjne), czynniki hormonalne (głównie estrogeny), ciąża. Guzy te mogą zajmować różne obszary anatomiczne, najczęściej obręcz barkową, ścianę klatki piersiowej, okolicę okołokręgosłupową, udo [2, 3]. W 20\% przypadków lokalizacja jest w ścianie klatki piersiowej, natomiast rzadko występują wewnątrz niej [2, 4]. Opisano nieliczne przypadki w obrębie śródpiersia tylnego [2, 5, 6]. Ocenia się, że zmiana ta może stanowić około $2 \%$ guzów śródpiersia [7]. Guzy tego typu mogą przebiegać bezobjawowo i są rozpoznawane przypadkowo $[2,5]$. Często wywołują jednak objawy powodowane uciskiem albo naciekaniem otaczających struktur, na przykład ucisk na nerwy wywołujący ból, na przełyk - dysfagię, czy na drogi oddechowe będący przyczyną duszności albo niewydolności oddechowej $[3,4,8]$. Fibromatoza nie daje przerzutów odległych i nie ma cytologicznych cech złośliwości. Uważana jest za mięsaka o niskim stopniu złośliwości. Charakteryzuje się lokalną inwazyjnością, naciekaniem i uciskiem na sąsiednie struktury [7, 8, 9]. W diagnostyce różnicowej uwzględnia się między innymi międzybłoniaka opłucnej, gruźlicę, włókniakomięsaka, chłoniaki, włóknienie śródpiersia, grasiczaki [7, 9]. W zwężeniu przełyku różnicowanie może dotyczyć jego zapalenia, nowotworów złośliwych, rozlanej mięśniakowatości gładkokomórkowej (leiomyomatosis). W diagnostyce wykorzystywane są przede wszystkim tomografia komputerowa (TK) oraz rezonans magnetyczny (MRI, magnetic resonance imaging) [1, 7, 9]. Ostateczne rozpoznanie ustala się jednak na podstawie badania histopatologicznego.

Leczenie fibromatosis jest głównie chirurgiczne i obejmuje wycięcie guza z szerokim marginesem, co najmniej $2 \mathrm{~cm}$. W niektórych przypadkach radykalna resekcja jest niemożliwa ze względu na sąsiedztwo ważnych dla życia struktur na przykład dużych naczyń albo ważnych pni nerwowych. W leczeniu stosowana jest też radioterapia jako metoda pojedyncza (w przypadkach nieoperacyjnych) albo skojarzona z leczeniem operacyjnym (po nieradykalnej resekcji guza) [2]. Opisano także zastosowanie chemioterapii, interferonu, hormonoterapii, imatynibu, niesteroidowych leków przeciwzapalnych, jak sulindak [10]. Do czynników prognostycznych nawrotu tego schorzenia zaliczono charakter guza (pierwotny lub nawrotowy), jego rozmiar i umiejscowienie oraz wiek chorego. Nawroty po leczeniu chirurgicznym, nawet radykalnym są częste i wynoszą średnio $40 \%$, występują także po radioterapii $[1,10]$. Śmiertelność z powodu tego schorzenia ocenia się na $0-8 \%$. W artykule przedstawiono rzadki przypadek guza śródpiersia u 26-letniego mężczyzny. Omówiono trudności w rozpoznaniu włókniakowatości śródpiersia.

\section{Opis przypadku}

Mężczyzna, lat 26, został przyjęty na oddział pulmonologii w grudniu 2010 roku z powodu nasilającej się od około 10 miesięcy duszności z dysfagią i odynofagią. W wywiadzie chory podawał informację o astmie oskrzelowej i alergii na pyłki traw, zbóż, żyta i olchy. W związku z tym był leczony przeciwastmatycznie. W wykonanej bronchofiberoskopii światło oskrzela głównego lewego było szczelinowato uciśnięte przez ucisk z zewnątrz i nie przepuszczało aparatu. W badaniu histopatologicznym skrawka z oskrzela stwierdzono skąpe, nieswoiste nacieki zapalne. W tomografii komputerowej klatki piersiowej (TK KLP) uwidoczniono guzowaty naciek w śródpiersiu pod ostrogą główną, w okolicy przełyku i wpustu mający gładkie zarysy i wymiary $6,5 \times$ $4,5 \times 6 \mathrm{~cm}$. Powodował on zwężenie lewego oskrzela głównego oraz przełyku. Ponadto, stwierdzono pogrubienie ściany wpustu oraz zwapnienie w części podwpustowej żołądka. Na tej podstawie podejrzewano, że widoczna zmiana może wychodzić ze ściany przełyku (ryc. 1). Gastroskopia potwierdziła cechy ucisku na przełyk oraz wpust. W seriogramie górnego odcinka przewodu pokarmowego obecne było przewężenie w górnym odcinku i modelowanie przełyku na obłym tworze. W endoskopowej ultrasonografii (EUS, endoscopic ultrasound), na wysokości $34 \mathrm{~cm}$ od siekaczy występował rozległy guz naciekający przełyk i sięgający około $5 \mathrm{~cm}$ w głąb śródpiersia, a na wpuście naciek z powiększeniem węzłów chłonnych do $11 \mathrm{~mm}$. Wynik badania cytologicznego z biopsji aspiracyjnej cienkoigłowej (BAC) wykonanej podczas EUS okazał się ujemny. Spirometria nosiła cechy umiarkowanego stopnia obturacji z ujemną próbą rozkurczową. Leki przeciwhistaminowe, rozszerzające oskrzela i wziewne glikokortykosteroidy spowodowały zmniejszenie duszności. W styczniu 2011 roku wykonano zwiadowczą torakotomię prawostronną. Podczas operacji stwierdzono pod rozwidleniem tchawicy guz śródpiersia średnicy około $6 \mathrm{~cm}$, obejmujący okrężnie przełyk od poziomu żyły 


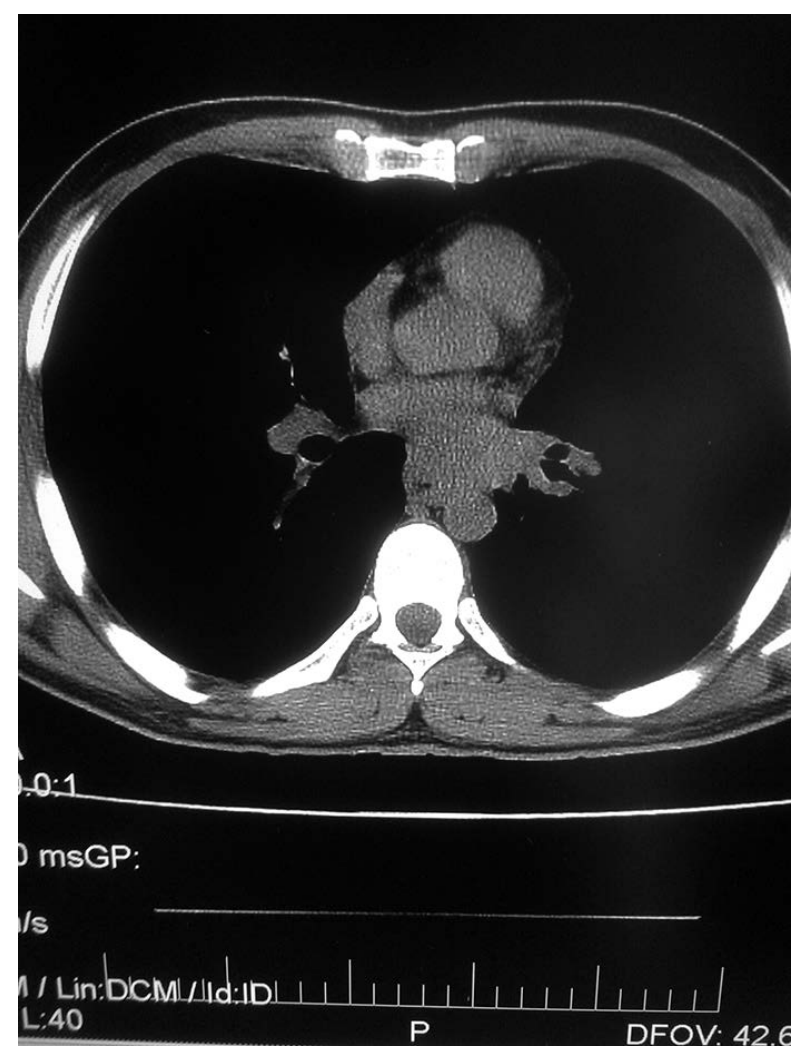

Rycina 1. Widoczny w obrazie tomografii komputerowej w śródpiersiu, podostrogowo guzowaty naciek o wymiarach $6,5 \times 4,5 \times 6 \mathrm{~cm}$. Na długości około $5 \mathrm{~cm}$ zmiana nie daje się odgraniczyć od przedniej ściany przełyku, którego światto jest w tym odcinku zaciśnięte

Figure 1. The CT scan image shows in the mediastinum an infracarinal tumorous infiltration, size $6.5 \times 4.5 \times 6 \mathrm{~cm}$. Alone ca. $5 \mathrm{~cm}$ the lesion cannot be separated from the anterior wall of the oesophagus the lumen of which in this section is tightened

nieparzystej do poziomu żyły płucnej dolnej i penetrujący między kręgosłupem a przedsionkiem pod rozwidleniem tchawicy na stronę lewą. Nadrzeponowo przy ścianie przełyku obecne były dwa węzły chłonne średnicy $1 \mathrm{~cm}$ i $1,5 \mathrm{~cm}$. Węzły pobrano i przesłano do badania doraźnego, które ustaliło ich charakter odczynowy. Następnie pobrano fragmenty guza i przesłano do badania śródoperacyjnego, które wykazało obecność tkanki łącznej włóknistej z ogniskami utkania tkanki limfoidalnej. Rozpoznanie zostało potwierdzone ostatecznym badaniem histopatologicznym materiału operacyjnego. W lutym 2011 roku był ponownie leczony na oddziale chorób płuc z powodu duszności wysiłkowej z towarzyszącym stridorem wdechowym. W bronchofiberoskopii utrzymywał się obraz szczelinowato zwężonego oskrzela głównego lewego. W trakcie bronchoskopii implantowano stent do lewego oskrzela głównego. Ze względu na stwierdzony limfoidalny charakter tkanki guza wysunięto podejrzenie

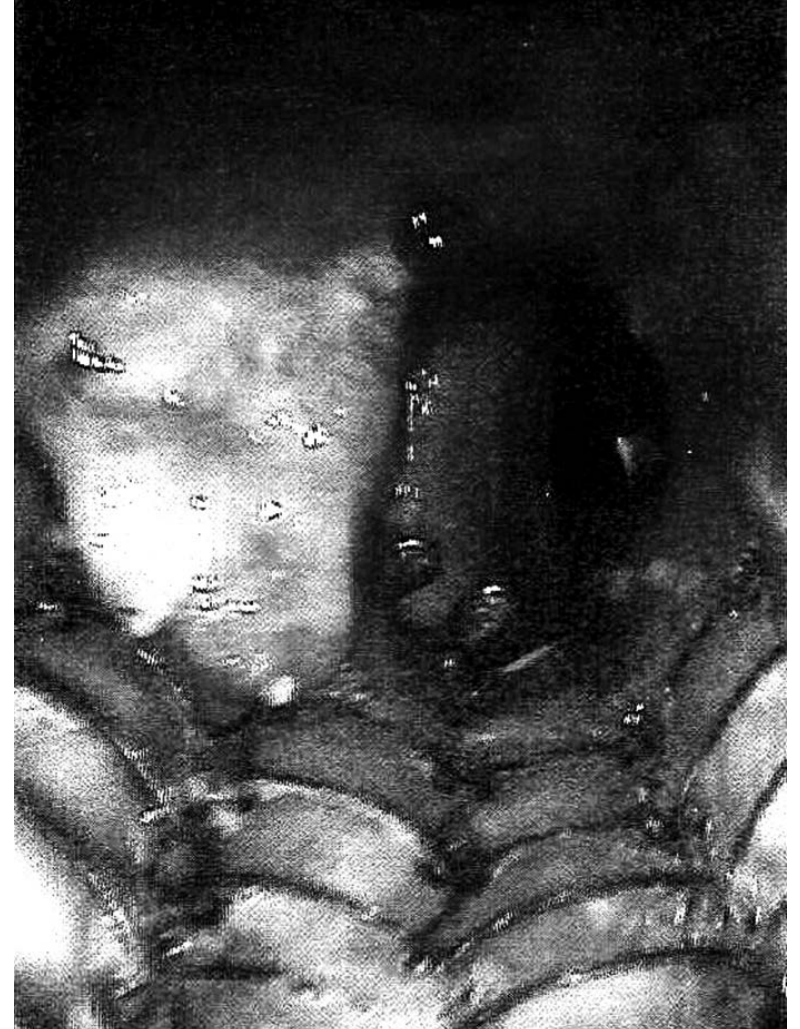

Rycina 2. Widoczny stent w oskrzelu głównym lewym. Przed jego początkiem oraz $\mathrm{w}$ jego dolnym odcinku obecna przerostowo zmieniona śluzówka

Figure 2. Visible stent in the left main bronchus. The mucous membrane before its beginning and in its bottom section has hypertrophic changes

chłoniaka. W wykonanej w maju 2011 roku TK KLP nie stwierdzono różnic w porównaniu z badaniem poprzednim, a w bronchofiberoskopii widoczny był stent w oskrzelu głównym lewym. Na jego końcach była obecna zmieniona przerostowo śluzówka, z której pobrano skrawki. Ujścia oskrzeli płata górnego i dolnego miały pogrubiałą śluzówkę, która zwężała ich światło do $1 / 2$ (ryc. 2). Wynik badania cytologicznego aspiratu z oskrzeli nie wykazał komórek nowotworowych. W badaniu histopatologicznym skrawka z oskrzela stwierdzono obraz zwłókniałej i ogniskowo owrzodziałej ściany oskrzela z obecnością nieswoistej, mocno unaczynionej ziarniny zapalnej. Na podstawie bakteriogramu wydzieliny oskrzelowej stwierdzono infekcję MSSA (Staphylococcus aureus metycilinowrażliwy). W trakcie konsultacji onkologicznej zalecono ponowne wykonanie gastroskopii oraz rozważenie radioterapii śródpiersia. W czerwcu 2011 roku w trakcie badań kontrolnych na oddziale chorób płuc wykluczono gruźlicę. W sierpniu tego samego roku pacjent był leczony na oddziale pulmonologii z powodu na- 
rastającej niewydolności oddechowej i duszności. W wykonanej wtedy bronchofiberoskopii widoczne były zmiany przerostowe zamykające światło lewego oskrzela głównego (przerastająca błona śluzowa). Wykonano udrożnienie laserowe zwężonego lewego oskrzela głównego z poprawą stanu klinicznego pacjenta. W badaniu histopatologicznym pobranych skrawków z oskrzela stwierdzono nacieczoną zapalnie błonę śluzową z ogniskiem wysoko dojrzałej metaplazji płaskonabłonkowej i nieswoistą ziarniną zapalną bez komórek nowotworowych. W badaniu spirometrycznym utrzymywały się cechy obturacji. Nadal obecna był infekcja MSSA. W listopadzie 2011 roku w bronchofiberoskopii stwierdzono dodatkowo nacieczenie ostrogi głównej. W badaniu histopatologicznym pobranych skrawków z oskrzela opisano błonę śluzową z naciekiem zapalnym, z dużym odsetkiem komórek plazmatycznych oraz strzępki włókniejącej ziarniny zapalnej bez obecności komórek nowotworowych. W 2011 i 2012 roku wielokrotnie wykonywano laserowe udrażnianie lewego oskrzela głównego. W 2012 roku pacjent był hospitalizowany na oddziale pulmonologii z powodu gronkowcowego (MSSA) zapalenia płuc. Wtedy też wykonano mechaniczne i laserowe udrożnienie lewego oskrzela głównego z lapisowaniem zmian przerostowych. W wykonanym badaniu histopatologicznym pobranych skrawków obecna była nieswoista ziarnina zapalna $\mathrm{z}$ owrzodzeniem i niewielkim włóknieniem. W TK KLP obraz zmiany był podobny jak w poprzednim badaniu. W maju 2012 roku z powodu nasilającej się duszności stwierdzono w wykonanym zdjęciu radiologicznym klatki piersiowej całkowite zacienienie lewego pola płucnego z przesunięciem śródpiersia w lewo. W bronchofiberoskopii oskrzele główne lewe było prawie całkowicie zamknięte przez przerostowo zmienioną śluzówkę na odcinku około 0,5 cm od ostrogi głównej. Wykonano TBNA (transbronchial needle aspiration) śródpiersia przez ostrogę główną. W badaniu histopatologicznym pobranych wycinków nie wykazano komórek nowotworowych. W kolejnej TK opisano dodatkowo przerośnięcie i przemieszczenie przełyku przez masy guzowate oraz niedodmę segmentów podstawnych płuca lewego. Węzły chłonne wnęk i śródpiersia nie były powiększone. Podczas ponownej hospitalizacji w lipcu 2012 roku w bronchofiberoskopii uwidoczniono oskrzele główne lewe zwężone przez pogrubiałą śluzówkę. W badaniu histopatologicznym pobranych skrawków utrzymywały się cechy zwłóknienia błony śluzowej oskrzela z nieswoistym naciekiem

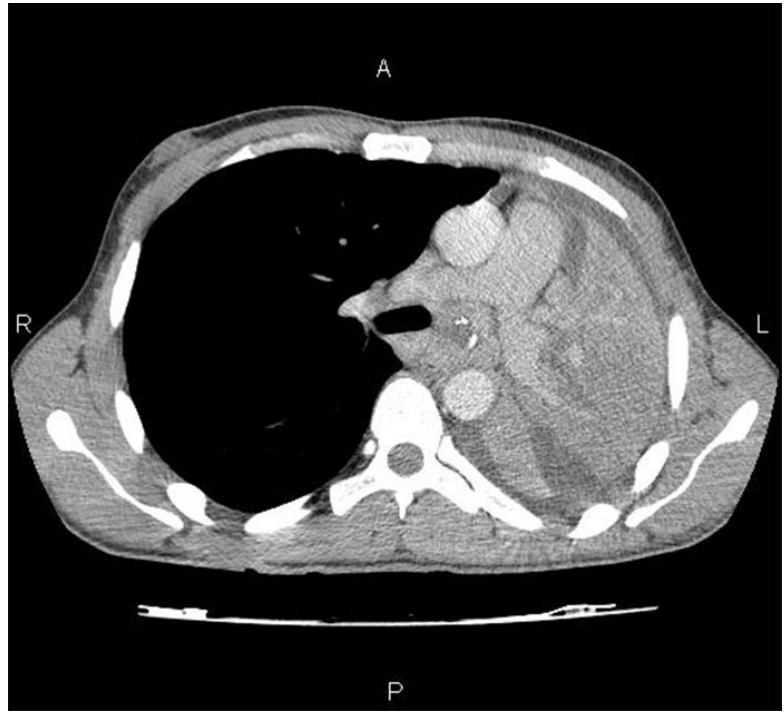

Rycina 3. Obraz tomografii komputerowej klatki piersiowej przedstawiający obecną w śródpiersiu masę guzowatą, która uciska i przemieszcza otaczające struktury (przełyk, tętnice płucne, lewy przedsionek). Guz nacieka i zamyka lewe oskrzele główne powodując niedodmę catego płuca lewego

Figure 3. Chest CT scan showing a tumorous mass present in the mediastinum, compressing and dislocating the structures (oesophagus, pulmonary arteries, left atrium). The tumour infiltrates and closes the left main bronchus, resulting in atelectasis of the entire left lung

zapalnym bez cech nowotworu. W spirometrii po raz pierwszy pojawiły się zmiany sugerujące restrykcję. W styczniu 2013 roku stwierdzono w radiogramie klatki piersiowej niedodmę płuca lewego, a w bronchofiberoskopii w oskrzelu głównym lewym pogrubiałą śluzówkę z masami martwiczymi. W odległości około $3 \mathrm{~cm}$ od ostrogi głównej ujście oskrzela głównego lewego było zwężone i nie przepuszczało fiberoskopu. W badaniu bakteriologicznym nadal wykazana była infekcja MSSA. W badaniu histopatologicznym pobranych wówczas skrawków nadal obecne były cechy zwłóknienia a w spirometrii umiarkowane zmiany sugerujące restrykcję. W TK KLP z maja 2013 roku stwierdzono progresję zmian w porównaniu z poprzednim badaniem. Guz naciekał i zamykał oskrzele główne lewe powodując niedodmę całego lewego płuca. Powodował ucisk i przemieszczenie otaczających struktur, tj. przełyku, tętnic płucnych i lewego przedsionka (ryc. 3). W prawym płucu w płacie górnym widoczne były dyskretne zmiany włókniste. W oknie aortalno -płucnym widniały węzły chłonne średnicy do $17 \mathrm{~mm}$, a w okolicy łuku aorty do $10 \mathrm{~mm}$. Wykonano EBUS (endobronchial ultrasound), TBNA, pobrano materiał na posiew, badanie cytologiczne i AFB (acid fast bacilii, bakterioskopia bezpośrednia w kierunku prątków kwasoodpornych). 


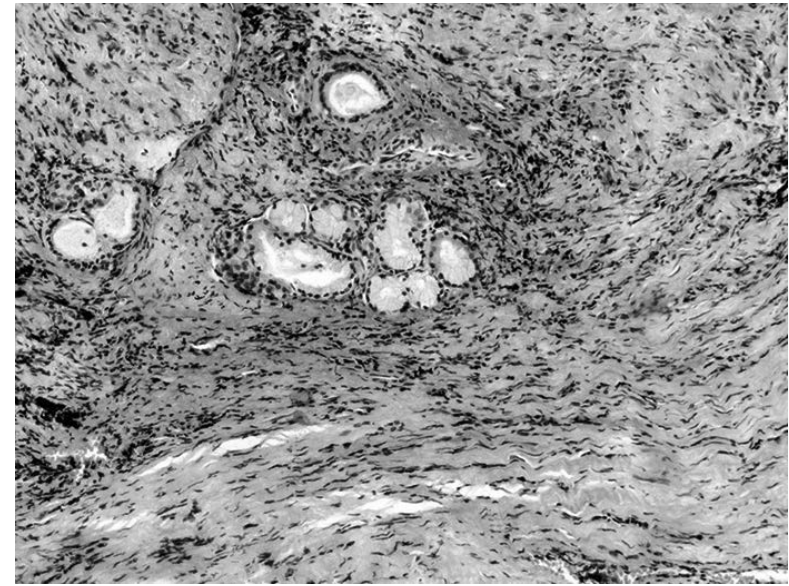

Rycina 4. Obecne włóknienie w obrębie ściany oskrzela ze zniszczeniem jego struktury

Figure 4. Fibrosis present within the region of the bronchial wall with destruction of its

Nadal nie ustalono charakteru zmiany śródpiersia. W gastroskopii wykonanej w czerwcu 2013 roku na Oddziale Chirurgii Klatki Piersiowej stwierdzono na głębokości $35 \mathrm{~cm}$ od linii zębów bliznowate zwężenie przełyku nieprzepuszczające standardowego endoskopu. $\mathrm{W}$ badaniu radiologicznym przełyku z kontrastem widoczne było zwężenie w środkowej części przełyku na długości około $2 \mathrm{~cm}$ do średnicy $5 \mathrm{~mm}$. Tuż nad wpustem przełyk i wpust żołądka były zwężone do $1 \mathrm{~mm}$, a na odcinku długości około $3 \mathrm{~cm}$ widoczna była guzowata zmiana zwężająca światło przełyku i przechodząca na wpust oraz obejmująca cały jego obwód. W badaniu EBUS stwierdzono, że oskrzele główne lewe na długości około $0,5 \mathrm{~cm}$ od ostrogi głównej było całkowicie zamknięte przez tkankę bliznowatą (pobrano skrawki, które odpowiadały poprzednim opisom histopatologicznym). W ultrasonografii nie uwidoczniono tkanki patologicznej do biopsji. Pacjenta zakwalifikowano do ponownej prawostronnej torakotomii zwiadowczej. Podczas zabiegu znaleziono w śródpiersiu wzdłuż przełyku masywny naciek ciągnący się od poziomu żyły nieparzystej do rozworu przełykowego przepony, który wciągał wnękę lewego płuca i przełyk (ucisk nie przepuszczał sondy). Pobrano liczne drobne skrawki z guza. W obrazie śródoperacyjnym widoczny był masywny odczyn włóknisty. Makroskopowo obraz przypominał chłoniaka. W badaniu histopatologicznym fragmentu nacieku wnęki i nacieku śródpiersia rozpoznano fibromatosis (ryc. 4, 5]. $\mathrm{W}$ diagnostyce immunohistochemicznej stwierdzono dodatnią reakcję na antygen mięśni gładkich (SMA, smooth muscle action) i ujemne od-

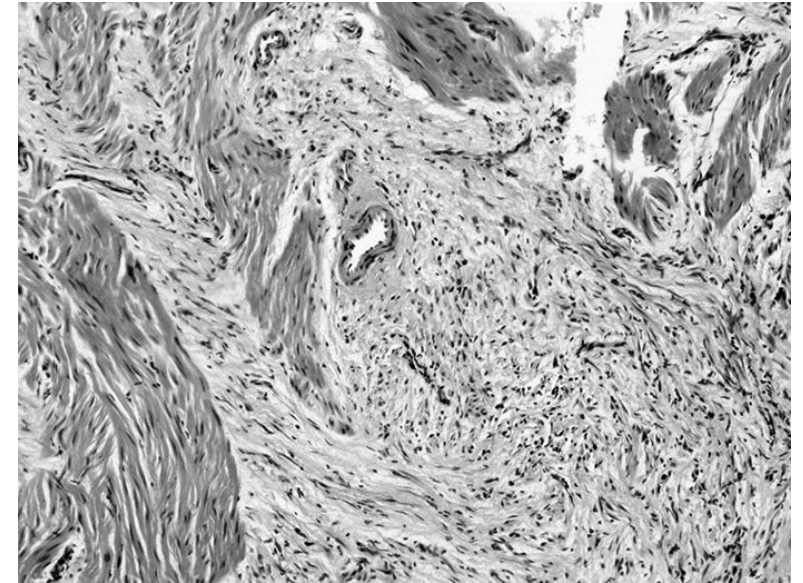

Rycina 5. Obecne włóknienie w otoczeniu przełyku z zajęciem jego mięśniówki

Figure 5. Fibrosis present within the region of the oesophagus, covering its muscle membrane

czyny CD34, bcl-2, PAS oraz Grocott. Ze względu na dysfagię wykonano u pacjenta gastrostomię. Następnie pacjent zakwalifikowany został do radioterapii.

\section{Dyskusja}

Rzadkość występowania włókniakowatości wewnątrz klatki piersiowej oraz niespecyficzny obraz kliniczny powodują znaczne trudności w jej rozpoznaniu mimo użycia wielu metod diagnostycznych. W literaturze znaleźć można jedynie pojedyncze przypadki tego nowotworu w obrębie śródpiersia. Przy objawach ze strony układu oddechowego zwykle jako pierwsze badanie obrazowe wykonuje się zdjęcie klatki piersiowej. Może ono pokazywać różne zmiany patologiczne, w tym guz śródpiersia i niedodmę, co obserwowano u przedstawionego chorego. W celu pogłębienia diagnostyki należy wykonać bardziej szczegółowe badania. Tomografia komputerowa pozwala ocenić wielkość, lokalizację, stopień naciekania guza na sąsiadujące narządy i stan węzłów chłonnych [1]. Rezonans magnetyczny jest bardziej czuły niż TK w diagnostyce naciekania struktur kostnych. W ocenie odpowiedzi na leczenie fibromatozy niektórzy autorzy stosują pozytronową tomografię emisyjną (PET, positron emission tomography). Badania obrazowe nie pozwalają jednak na ostateczne rozpoznanie rodzaju guza. Biopsja aspiracyjna cienkoigłowa może je jedynie sugerować $[3,7,10]$, a jego ostateczne potwierdzenie jest możliwe jedynie na podstawie badania histopatologicznego [7]. U opisywanego pacjenta początkowo rozpoznano niespecyficzną limfadenopatię 
śródpiersia z podejrzeniem chłoniaka. Badania histopatologiczne skrawków pobieranych wielokrotnie z nacieczonego oskrzela, analiza wycinków uzyskanych podczas pierwszej operacji oraz badania śródoperacyjne nie pozwoliły na postawienie ostatecznej diagnozy, mimo konsultacji patomorfologicznych z innymi ośrodkami w kraju i za granicą. Ustalono ją dopiero, oceniając bloczki parafinowe wycinków z guza otrzymanymi w czasie drugiej operacji i wykonując dodatkową diagnostykę immunohistochemiczną. W tym przypadku wykonano u pacjenta częściową resekcję guza i poddano go następowej radioterapii. Obecnie pozostaje pod opieką poradni onkologicznej.

W literaturze, temat fibromatozy zlokalizowanej wewnątrz klatki piersiowej nie pojawia się często. Sharma V. i wsp. opublikowli serię 42 pacjentów (28 kobiet i 14 mężczyzn) o średniej wieku 33 lata, gdzie u jedynie 5 osób występowała lokalizacja wewnątrzklatkowa [11]. Z kolei Kasper B. i wsp. opisali grupę 9 chorych z włókniakowatością. U dwóch występowała postać intratorakalna [12].

Rzadki charakter lokalizacji włókniakowatości, a w związku z tym duże trudności z uzyskaniem materiału tkankowego reprezentatywnego do postawienia rozpoznania patomorfologicznego, determinuje istotny wpływ zespołu konsultującego. W jego skład, poza patomorfologiem, powinni wejść doświadczony klinicysta i radiolog, dla których problematyka tego rodzaju chorób, w takiej lokalizacji nie będzie jedynie literaturową kazuistyką.

\section{Conflict of interest}

The authors declare no conflict of interest.

\section{References}

1. Wilhelm A., Jolles H.I., Krishna M. Anterior mediastinal desmoid tumor with CT and MR imaging. J. Thorac. Imaging 2007; 22: 252-255.

2. Reiter M., Schwope R. Intrathoracic desmoid type fibromatosis: a case report and literature review. J. Surg. Radiol. 2012; 3: $184-188$.

3. Cardoso P.F.G., da Silva L.C.C., Bonamigo T.P. et al. Intrathoracic desmoids tumor with invasion of the great vessels. Eur. J. Cardiothorac. Surg. 2002; 22: 1017-1019.

4. Kawashima A., Fishman E.K., Hruban R.H. i wsp. Intrathoracic paraspinal desmoids with intracanalicular extension: computed tomography and magnetic resonance imaging findings. Orthopedics 2000; 23: 381-382.

5. Saw E., Yu G.S., Mell M. Desmoid tumor of the sternum presenting as an anterior mediastinal mass. Eur. J. Cardiothorac. Surg. 1997; 11: 384-386.

6. Dosios T.J., Angouras D.C., Floros D.G. Primary desmoid tumor of the posterior mediastinum. Ann. Thorac. Surg. 1998; 66: 2098-2099.

7. Lone G.N., Bhat M.A., Noor Ali M.Ch. i wsp. Cervico-thoracic and cervico-thoracic- mediastinal fibromatosis- Rare entity and locally malignant disease. Ind. J. Cardiothoracovasc. Surg. 2004; 20: 197-200.

8. Yoruk Y., Karamustafaoglu Y.A., Sezer Y.A. i wsp. Extra-Abdominal Aggressive Fibromatosis Presenting As an Intrathoracic Tumor. Trakya Univ. Tip. Fak. Derg. 2010; 27: 302-304.

9. Inase N., Ichioka M., Akamatsu H. i wsp. Mediastinal Fibromatosis Presenting with Superior Vena Cava Syndrome. Respiration 1999; 66: 464-466.

10. Sze H., Yeung M.W. Fibromatosis of the neck causing airway obstruction managed effectively with weekly low-dose methotrexate and vinblastine. Hong Kong Med. J. 2009; 15: 221-223.

11. Sharma V., Chetty D.N., Donde B. i wsp. Aggressive fibromatosis- impact of prognostic variables on management. South Afr. J. Surg. 2006; 44: 6-11.

12. Kasper B., Dimitrakopoulou-Strauss A., Strauss L.G. i wsp. Positron emmision tomography in patients with aggressive fibromatosis/desmoid tumours undergoing therapy with imatinib. Eur. J. Nucl. Med. Mol. Imaging 2010; 37: 1876-1882. 